\title{
Determinants of Diarrhea in Under-Five Children Among Health Extension Model and Non-Model Families in Wama Hagelo District, West Ethiopia: Community-Based Comparative Cross-Sectional Study
}

\author{
Desalegn Bekele' \\ Elias Merdassa (iD) \\ Markos Desalegn (iD) \\ Getu Mosisa (iD) ${ }^{2}$ \\ Ebisa Turi iD ' \\ 'Department of Public Health, Wollega \\ University, Nekemte, Oromia Region, \\ Ethiopia; ${ }^{2}$ School of Nursing and \\ Midwifery, Wollega University, Nekemte, \\ Oromia Region, Ethiopia
}

Correspondence: Markos Desalegn Department of Public Health, Wollega University, Nekemte, Oromia Region, Ethiopia

Tel +251927619190

Email markosdesalegn@gmail.com
Background: Diarrhea is a major leading cause of under-five morbidity and mortality in developing countries. Although the health extension program has been implemented for decades, diarrhea continues to be a major public health problem.

Objective: To determine determinants of diarrhea among under-five-year-old children in the health extension model and non-model families of Wama Hagelo District 2019.

Methods: A community-based comparative cross-sectional study was conducted among 512 under-five children among 257 model and 255 non-model health extension families. A multi-stage sampling technique was used. Households with at least one under-five child were selected using a simple random sampling method. Data were collected using an interviewer-administered questionnaire. Bivariate analysis was done to select candidate variables at $p \leq 0.2$. Determinants of childhood diarrhea were determined by a multivariable logistic regression model at $p$-value less than 0.05 .

Results: The two-week prevalence of diarrhea among under-five children in model and non-model families was 7.8\% (95\% CI=4.5-11.1\%) and 27.8\% (95\% CI 22.3-33.3\%), respectively. Unimproved water sources $(\mathrm{AOR}[95 \% \mathrm{CI}]=5.5[2.2,97.7])$ and no vaccination against Rotavirus $(\mathrm{AOR}[95 \% \mathrm{CI}]=49.8[4.2-94.8])$ were associated with diarrhea among under-five children in model families. Family size $>5(\mathrm{AOR}[95 \% \mathrm{CI}]=5.2[1.7-17.6])$, using unimproved water sources $(\mathrm{AOR}[95 \% \mathrm{CI}]=7.2[1.6-13.2])$, not using latrine $(\mathrm{AOR}[95 \% \mathrm{CI}]=6[1.8-20.6])$, child not vaccinated against Rotavirus (AOR $[95 \% \mathrm{CI}]=10.9$ [2.9-41.1]), child not supplemented with vitamin A (AOR [95\% CI] = 3.2 [1.4-7.2]), and not being health extension model families (AOR $[95 \% \mathrm{CI}]=2.4[1.15-4.99])$ predict diarrhea among under-five children in non-model families.

Conclusion: Diarrhea was more frequent among non-model than model families. Family size, type of water source, using a latrine, place of childbirth, child vaccination against Rotavirus, and vitamin A supplementation were independently associated with the occurrence of diarrhea in under-five children. Encouraging all non-model families to become models in implementing all health extension packages by strengthening community participation is important to decrease childhood diarrhea in under-five children. Keywords: under-five diarrhea, model and non-model families

\section{Background}

Diarrhea is the passage of loose or watery stools at least 3 times per 24-hour period. ${ }^{1}$ The community and the child caregivers can understand this abnormal 
deviation of passing stools on themselves as well as on their children. ${ }^{2}$ It occurs in a situation where there is social unrest like political instability and migration, and poor socioeconomic status, factors which are leading to overcrowded conditions, lack of adequate clean water, and inappropriate waste disposal systems, and finally causing morbidity and mortality, and putting the vulnerable groups of society, especially children, at higher risks. ${ }^{3}$

Under-five-year-old children suffering from frequent diarrhea consequently face poor growth and cognitive development as well as severe malnutrition due to its repeat attack, with the average frequency of about 3 and more times per year, though it varies with child age and place. ${ }^{4,5}$ Diarrhea is the second leading cause of death among children less than five years worldwide, ${ }^{6}$ and causes economic loss in developing countries by contributing to more than one-third of hospital beds being occupied by diarrhea patients requiring a high amount of expensive intravenous medicine. ${ }^{7}$ The prevalence of childhood diarrhea is different across different countries according to the country's specific status of diarrhea determining factors, and therefore the burden is increased in developing countries such as Asian and Sub-Saharan African countries where about threefourths of the problem is confined. ${ }^{8,9}$

Ethiopian Health Sector policy and strategies have been highly focusing on common communicable diseases prevention and control by implementing health extension programs at a community level by ensuring community participation through facilitating families to apply all 16 Health Extension Programs (HEP). The services provided under HEP include 16 essential health programs under four major program areas, namely hygiene and environmental sanitation which includes seven programs and is directly related to communicable diseases likes diarrhea: 1) proper and safe excreta disposal system, 2) proper and safe solid and liquid waste management, 3) water supply safety measures, 4) food hygiene and safety measures, 5) healthy home environment, 6) arthropod and rodent control, and 7) personal hygiene. Disease prevention and control include four programs: 1) HIV/AIDS prevention and control, 2) TB prevention and control, 3) malaria prevention and control, and 4) first aid. The family health services area includes five programs: 1) maternal and child health, 2) family planning, 3) immunization, 4) adolescent reproductive health, and 5) nutrition. The fourth major program area is health education and communication.

It is through these programs that the community is incapacitated to implement the programs on their family to prevent their family from communicable diseases, and certified and entitled health extension model family when they fully apply all the packages. Unless families apply almost all HEPs to their life, it is only ideal that communities are free from communicable diseases and hence HEP non-model families are susceptible to diarrheal diseases. ${ }^{10,11}$ One of the positive outcomes of increasing the number of model families is the decreased prevalence of diarrhea among children less than five years old in these families. Therefore this study was to comparatively determine the status of diarrhea among under-fives between health extension model and non-model families in Wama Hagelo District, East Wollega, West Ethiopia.

\section{Methods}

\section{Study Area and Period}

This study was conducted starting from July 1, 2019, up to August 30, 2019, in Wama Hagelo District - one of the 17 Districts of East Wollega zone located in Western Ethiopia. The district has been structured into 10 rural and 2 urban kebeles with a total population of 65,250 , in 13,042 households, from which about 900 families were certified as being health extension model families. The district has 4 health centers, 16 health posts, and 41 health extension workers. From the total of 10 rural kebeles, 2 had declared themselves "open-defecation-free" (ODF) kebeles. According to the inventory of latrines conducted by HEWs in 2017 , about $75 \%$ of households had basic latrines, while $63 \%$ had improved latrines. The total number of children under five years of age was 10,702.

\section{Study Design and Population}

A community-based comparative cross-sectional study was conducted in Wama Hagelo District, East Wollega, West Ethiopia. The source population of this study was all children living in Wama Hagelo District, and the study population was all under-five children living in a selected 6 kebeles of the district. Randomly selected under-five children from sampled households were considered as the study unit in this study. Under-five children living in the District for at least the last 6 months were included in the study; under-five children with chronic diarrhea and 
children less than 6 months were excluded from the study. In cases where households have more than one under-five child, the younger or index child was selected as respondent.

\section{Sample Size Determination and Sampling Procedures}

The sample size was determined using the assumptions that the expected proportion of childhood diarrhea among model families was $8.1 \%$, and among non-model families $20.2 \%{ }^{12}$ Furthermore, a 5\% level of significance, $95 \%$ confidence level, $80 \%$ power of the study, ratio of $1: 1$ model to non-model families, $5 \%$ non-response, and two design effect formula were used.

$$
n=\left(\frac{r+1}{r}\right) \cdot\left(\frac{(P)(1-P)\left(Z \beta+\frac{Z \alpha}{2}\right) 2}{(P 1-P 2)^{2}}\right) 13
$$

where $\mathrm{P} 1=0.081, \mathrm{P} 2=0.202, \mathrm{q} 1=0.919, \mathrm{q} 2=0.798$, $95 \% \mathrm{CI}=\mathrm{Z} \alpha / 2=1.96$, Power $80 \%=0.84$. Then $\mathrm{n} 1=129$ for model families and 129 for non-model families. Adding a 5\% non-response rate and design effect of " 2 ", the maximum possible calculated samples size was 528 .

A multi-stage sampling technique was employed to select study participants in the 12 kebeles which were stratified into urban and rural kebeles. One urban and 5 rural kebeles were selected using simple random sampling from a cluster-created sample frame as the primary sampling unit. Then Probability proportional to sample size allocation was done to each selected kebele. Finally, simple random sampling was applied to select 264 model and 264 non-model families with at least one under-five child as a basic sampling unit (Supplementary Figure 1).

\section{Study Variables}

Dependent Variable

- Occurrence of diarrhea in under-five children within 2 weeks before data collection.

\section{Independent Variables}

- Socio-demographics (family size, maternal educational level, place of residence, family income, child sex, age of child, number of U5C in household).

- Environmental factors (source of drinking water, time to reach water source, toilet availability, hand washing practice, availability of waste disposal system)

- Obstetrics factor (child birthplace).

- Child health care practice (child vaccination status, child feeding practice, vitamin A supplementation, measles infection).

\section{Operational Definitions}

\section{Diarrhea in Under-Five Children}

This is defined as the experience in a child of under-five years of age of three or more loose or watery stools in 24 hours during or within the two weeks before the survey, as reported by the mother/caretaker of the child.

\section{Health Extension Model Family}

Families who implemented more than $85 \%$ of all HEP and were certified by the District Health Office, Health Center, or Kebele administration. ${ }^{10}$

\section{Health Extension Non-Model Families}

Families who did not implement at least $85 \%$ of all HEP and were not certified by the District Health Office, Health Center, or Kebele administration. ${ }^{10}$

\section{Solid Waste Disposal Methods}

Disposing of refuse by burning, burying in a pit or storing in a container, composting, and disposing of in a designated site is considered as "proper" disposal, whereas disposing of refuse in open field is considered as "improper" disposal.

\section{Index Child}

This is a child included in the study from a household to have information related to the study. The youngest child in the household is included in the study.

\section{Prevalence of Diarrhea}

This is the total number of children with diarrhea among children aged 6 months to 5 years that occurred during the 2 weeks before data collection, divided by the total number of surveyed under-five children in the study area.

\section{Improved Water Sources}

It includes piped water into dwelling, piped water to yard/ plot, tube well or borehole, public standpipes, protected dug wells, protected springs, and rainwater. An "improved" source is likely to provide "safe water". 


\section{Unimproved Water Sources}

They are unprotected dug wells, unprotected springs, cart with small tank/drum, tanker-truck, surface water (rivers, dams, lakes, ponds, streams, canals, and irrigation channels).

\section{Improved Latrine}

This category includes flush toilet, piped sewer system, septic tank, ventilated improved pit latrine (VIP), pit latrine with slab, and composting toilet.

\section{Unimproved Toilet}

This category includes a flush/pour flush to elsewhere, a pit latrine without slab, bucket, hanging toilet or hanging latrine, no facilities, or bush or field.

\section{Data Collection Methods and Instrument} Initially, the pretested and interviewer-administered structured questionnaire prepared in English language and translated to Afaan Oromo language was used to collect data. The tool/questionnaire has three sections: sociodemographic section (13 items), environmental factors section (18 items), and child health care practice section (21 items). It was adopted from other tools used in a similar study to collect data from mothers/caregivers face to face. ${ }^{14}$ The interviewers observed the condition of household water handling practices and the utilization of sanitation facilities using an observation checklist. The supervisors were fully responsible to lead and handle the whole session of the data collection process along with the principal investigator.

\section{Data Processing and Analysis Plan}

The data were checked for completeness and consistency for data entry and cleaning. Then, the data were coded and entered using SPSS version 24 for analysis. The outcome variable, childhood diarrhea in under-five children, was dichotomized by assigning " 1 " for those who had diarrhea and " 0 " for those who did not have diarrhea. Initially, descriptive statistics were done; frequency and proportion were calculated for categorized independent variables. Mean and standard deviation were calculated for independent variables. Univariate analysis was computed of the association between socio-demographic characteristics, environmental factors, and child health care practice with HEP implementation among model and non-model families. Then bivariable logistic regression analysis was done to select candidate variables using a significance level of $p=0.2$. Independent predictors of childhood diarrhea were determined by a multivariable logistic regression model at $p$-value less than 0.05. Finally, adjusted odds ratio with its $95 \%$ confidence interval was reported.

Hosmer and Lemeshow's goodness-of-fit test was used to test for model fitness. ${ }^{15}$ The independent variables were tested for multicollinearity using the variance inflation factor (VIF), and variables indicating above the tolerable value of greater than 10 were excluded as the presence of multicollinearity.

\section{Data Quality Control}

The questionnaire was prepared in simple and easily understandable English language. The questions were closed-ended to prevent the probability of information bias. Data collectors were trained on how to interview mothers, and fill the questionnaire to ensure that they were efficient enough to carry out the actual study. Pretest was performed among $5 \%$ of the sample size, 26 households, before actual data collection, to check the appropriateness of the tool to collect information, and the necessary amendments were made. Data collectors were assigned in a different direction in the kebele, and households were surveyed thoroughly. The overall data collection process was monitored by supervisors. Filled questionnaires were reviewed after every day in the field for completeness and other errors by supervisors.

\section{Results}

Socio-Demographic Characteristics of Study Participants in Wama Hagelo

\section{District, 2019}

A total of 512 caregivers of under-five children participated in the study, 257 (97.3\%) caregivers from the health extension model and 255 (96.6\%) caregivers from nonmodel families, making a response rate of $96.7 \%$ (Table 1). From a total of 512 respondents, 497 (97\%) respondents were the mother of the index child - 257 (100\%) from model families and 240 (94\%) from nonmodel families. The majority of the respondents -138 (53.7\%) of model families and 134 (52.5\%) of non-models families - were of Protestant religion, followed by Orthodox religion, $92(35.8 \%)$ in model and 74 (29\%) in non-model families. 
Table I Socio-Demographic and Economic Characteristics of Model and Non-Model Families in Wama Hagelo Woreda, East Wollega, Oromia, Ethiopia, 2019

\begin{tabular}{|c|c|c|c|}
\hline \multirow[t]{2}{*}{ Variables } & \multirow[t]{2}{*}{ Categories } & \multicolumn{2}{|c|}{ HH HEP Implementation Status } \\
\hline & & Model (\%) & Non-Model (\%) \\
\hline \multirow{2}{*}{ Residence of respondents } & Urban & $9(3.5 \%)$ & $9(3.5 \%)$ \\
\hline & Rural & $248(96.5 \%)$ & $246(96.5 \%)$ \\
\hline \multirow[t]{2}{*}{ Respondent's relation with children in $\mathrm{HH}$} & Mother & 255 (99.2\%) & $251(98.4 \%)$ \\
\hline & Other & $2(0.8 \%)$ & $4(1.6 \%)$ \\
\hline \multirow[t]{5}{*}{ Age category of respondents } & $15-19$ & $0(0.0 \%)$ & $9(3.5 \%)$ \\
\hline & $20-24$ & $42(16.3 \%)$ & $38(14.9 \%)$ \\
\hline & $25-29$ & 78 (30.4\%) & $82(32.2 \%)$ \\
\hline & $30-34$ & $57(22.2 \%)$ & $57(22.4 \%)$ \\
\hline & $35+$ & $25(9.7 \%)$ & $9(3.5 \%)$ \\
\hline \multirow[t]{2}{*}{ Marital status } & Single & $0(0 \%)$ & I (0.4\%) \\
\hline & Ever married & 257 (96.9\%) & $254(99.6 \%)$ \\
\hline \multirow[t]{4}{*}{ Religion of respondents } & Orthodox & $92(35.8 \%)$ & $74(29.0 \%)$ \\
\hline & Muslim & $23(8.9 \%)$ & $31(12.2 \%)$ \\
\hline & Protestant & I 38 (53.7\%) & 134 (52.5\%) \\
\hline & Other & $4(1.6 \%)$ & $16(6.3 \%)$ \\
\hline \multirow[t]{3}{*}{ Ethnicity } & Oromo & 244 (94.9\%) & $219(85.9 \%)$ \\
\hline & Amharic & $5(1.9 \%)$ & 15 (5.9\%) \\
\hline & Other & $8(3.1 \%)$ & $21(8.2 \%)$ \\
\hline \multirow[t]{4}{*}{ Educational level of caretaker } & Illiterates & $90(35.2 \%)$ & 115 (45.1\%) \\
\hline & Write and read only & $15(5.8 \%)$ & $40(15.7 \%)$ \\
\hline & Grade I-8 & $110(42.8 \%)$ & 71 (27.8\%) \\
\hline & Grade $9-12$ and above & $42(16.3 \%)$ & $29(11.4 \%)$ \\
\hline \multirow[t]{4}{*}{ Occupation of respondents } & Housewife & $113(44.0 \%)$ & 121 (47.5\%) \\
\hline & Farmer & 115 (44.7\%) & $87(34.1 \%)$ \\
\hline & Merchant & $26(10.1 \%)$ & $38(14.9 \%)$ \\
\hline & Employ in private & $3(1.2 \%)$ & $9(3.6 \%)$ \\
\hline \multirow[t]{3}{*}{ Whether father or mother of child alive } & Both parents alive & 247 (96.1\%) & 237 (92.9\%) \\
\hline & Either alive & $7(2.7 \%)$ & $16(6.3 \%)$ \\
\hline & Both parents died & $3(1.2 \%)$ & $2(0.8 \%)$ \\
\hline \multirow[t]{4}{*}{ Educational level of child's father } & Illiterates & $44(17.5 \%)$ & $70(30.2 \%)$ \\
\hline & Write and read only & $22(8.8 \%)$ & II (4.7\%) \\
\hline & Grade I-8 & 91 (36.3\%) & 79 (34.1\%) \\
\hline & Grade $9-12$ and above & $94(37.5 \%)$ & $72(31.0 \%)$ \\
\hline \multirow[t]{2}{*}{ Average family size } & $\leq 5$ & I 65 (64.2\%) & 97 (38.0\%) \\
\hline & $>5$ & $92(35.8 \%)$ & I 58 (62.0\%) \\
\hline \multirow[t]{4}{*}{ Family monthly income } & $\leq 1000$ & $80(31.1 \%)$ & $158(62.0 \%)$ \\
\hline & $100 \mid-2000$ & $69(26.8 \%)$ & 65 (25.5\%) \\
\hline & $200 I-3000$ & 47 (I8.3\%) & $23(9.0 \%)$ \\
\hline & $>3000$ & 61 (23.7\%) & 9 (3.5\%) \\
\hline
\end{tabular}

A total of $135(52.5 \%)$ respondents of model and 145 $(56.9 \%)$ of non-model families were in the age category of 25-34 years; the mean age was $20.10 \pm 6.41$. The average family size of the respondents was 5.6, with average size among model families being 5.37, and 5.84 among nonmodel families. 


\section{Environmental Risk Factors for Diarrhea Among Participants in Wama Hagelo District, 2019}

A total of 248 (96.5\%) of model and 201 (78.8\%) of non-model families were using drinking water from an improved source. The majority, 155 (60.3\%) of model and $49(19.2 \%)$ of non-model families, were treating water for drinking purposes at the household level. Almost all, 257 (100\%) of model and 215 (84.3\%) of non-model families, were using a latrine. A total of $233(90.7 \%)$ of model and $102(47.2 \%)$ of non-model families' latrines had hand washing facilities (Table 2).
Child Health Care Practices and Prevalence of Diarrhea Among Participants in Wama Hagelo District, 2019

The majority, 148 (57.1\%) of model and 134 (52.5\%) of non-model families, had only one child. The average number of under-five children in the family was $1.47 \pm$ 0.57 among model and $1.54 \pm 0.61$ among non-model families (Figure 1). Almost all children, 255 (99.2\%) children of model families and 213 (83.5\%) children of non-model families, were born at a health facility (Table 3). The overall prevalence of diarrhea among

Table 2 Environmental Risk Factors for Diarrhea Among U5C of Model and Non-Model Families in Wama Hagelo Woreda, Oromia, Ethiopia, 2019

\begin{tabular}{|c|c|c|c|}
\hline \multirow[t]{2}{*}{ Variables } & \multirow[t]{2}{*}{ Categories } & \multicolumn{2}{|c|}{ HH HEP Implementation Status } \\
\hline & & Model (\%) & Non-Model (\%) \\
\hline \multirow[t]{2}{*}{ Types of water sources for drinking } & Improved sources & $248(96.5 \%)$ & $20 \mathrm{I}(78.8 \%)$ \\
\hline & Unimproved sources & $9(3.5 \%)$ & 54 (2।.2\%) \\
\hline \multirow[t]{2}{*}{ Time taken to reach water sources in $\mathrm{min}$} & $\leq 15 \min$ & 189 (73.5\%) & $170(66.7 \%)$ \\
\hline & $>15 \mathrm{~min}$ & $68(26.5 \%)$ & $85(33.3 \%)$ \\
\hline \multirow[t]{2}{*}{ Household level water treatment } & Do not treat & $102(39.7 \%)$ & $206(80.8 \%)$ \\
\hline & Treat at home & $155(60.3 \%)$ & $49(19.2 \%)$ \\
\hline \multirow[t]{2}{*}{ Washing hands with water and soap at critical times } & Yes & $250(97.3 \%)$ & $164(64.3 \%)$ \\
\hline & No & $7(2.7 \%)$ & $91(35.7 \%)$ \\
\hline \multirow[t]{2}{*}{ Amount of water used in liters per person per day } & $<7.5 \mathrm{~L}$ & $185(72.0 \%)$ & $195(76.5 \%)$ \\
\hline & $\geq 7.5 \mathrm{~L}$ & $72(28.0 \%)$ & $60(23.5 \%)$ \\
\hline \multirow{2}{*}{ Washing hands with water and soap } & Wash at all critical time & I 88 (74.9\%) & $82(50.3 \%)$ \\
\hline & Wash soap partially & $63(25.1 \%)$ & $81(49.7 \%)$ \\
\hline \multirow[t]{2}{*}{$\mathrm{HH}$ using latrine } & Yes & $257(100.0 \%)$ & $215(84.3 \%)$ \\
\hline & No & & $40(15.7 \%)$ \\
\hline \multirow[t]{3}{*}{ Availability of hand washing facility near latrine } & No hand washing facility & $12(4.7 \%)$ & $62(29.0 \%)$ \\
\hline & Only water available & $12(4.7 \%)$ & $5 \mathrm{I}(23.8 \%)$ \\
\hline & All facilities available & $233(90.7 \%)$ & $102(47.2 \%)$ \\
\hline \multirow[t]{2}{*}{ Type of latrine } & Improved & $257(100.0 \%)$ & $106(49.3 \%)$ \\
\hline & Unimproved & & $109(50.7 \%)$ \\
\hline \multirow{2}{*}{$\begin{array}{l}\text { Distance between latrine and drinking water } \\
\text { sources }\end{array}$} & $<30 \mathrm{~m}$ & $48(18.7 \%)$ & $51(20.0 \%)$ \\
\hline & $\geq 30 \mathrm{~m}$ & $209(81.3 \%)$ & $204(80.0 \% 0$ \\
\hline \multirow[t]{2}{*}{ Availability of solid-waste disposal system } & Yes & $233(90.7 \%)$ & $87(34.1 \%)$ \\
\hline & No & $24(9.3 \%)$ & $168(65.9 \%)$ \\
\hline \multirow{2}{*}{$\begin{array}{l}\text { Availability of liquid-waste disposal system for } \mathrm{HH} \\
\text { use }\end{array}$} & Yes & $101(39.3 \%)$ & 14 (5.5\%) \\
\hline & No & $156(60.7 \%)$ & $24 \mathrm{I}(94.5 \%)$ \\
\hline
\end{tabular}


Table 3 Child Health Care Practice of Model and Non-Model Families in Wama Hagelo Woreda, Oromia, Ethiopia, 2019

\begin{tabular}{|c|c|c|c|}
\hline \multirow[t]{2}{*}{ Variables } & \multirow[t]{2}{*}{ Categories } & \multicolumn{2}{|c|}{ HH HEP Implementation Status } \\
\hline & & Model (\%) & Non-Model (\%) \\
\hline \multirow{2}{*}{ Number of $\mathrm{U} 5 \mathrm{C}$ in $\mathrm{HH}$} & I & $148(57.6 \%)$ & $134(52.5 \%)$ \\
\hline & $\geq 2$ & $109(42.4 \%)$ & $121(47.5 \%)$ \\
\hline \multirow[t]{2}{*}{ Sex of index child } & Male & 118 (45.9\%) & 117 (45.9\%) \\
\hline & Female & $139(54.1 \%)$ & $138(54.1 \%)$ \\
\hline \multirow[t]{4}{*}{ Age of index child } & $0-6$ months & 29 (II.3\%) & $26(10.2 \%)$ \\
\hline & $7-11$ months & $64(24.9 \%)$ & $52(20.4 \%)$ \\
\hline & $12-23$ months & $68(26.5 \%)$ & $41(16.1 \%)$ \\
\hline & 24-59 months & $96(37.4 \%)$ & $136(53.3 \%)$ \\
\hline \multirow[t]{2}{*}{ Place of childbirth } & Health facility & 255 (99.2\%) & $213(83.5 \%)$ \\
\hline & Home & $2(0.8 \%)$ & $42(16.5 \%)$ \\
\hline \multirow[t]{3}{*}{ Time at initiation of breastfeeding } & Before I hour & 237 (92.2\%) & $214(83.9 \%)$ \\
\hline & I-8 hours & $15(5.8 \%)$ & $30(11.8 \%)$ \\
\hline & 8 hours -3 days & $5(1.9 \%)$ & II (4.3\%) \\
\hline \multirow[t]{2}{*}{ EBF status } & EBF & $248(96.5 \%)$ & $182(7 \mid .4 \%)$ \\
\hline & Not EBF & $9(3.5 \%)$ & $73(28.6 \%)$ \\
\hline \multirow[t]{3}{*}{ Age at complementary feeding initiation } & Age 6 month & 145 (61.7\%) & 47 (19.7\%) \\
\hline & Before 6 month & $9(3.8 \%)$ & 70 (29.4\%) \\
\hline & After 6 month & 81 (34.5\%) & $|2|(50.8 \%)$ \\
\hline \multirow[t]{2}{*}{ Types of complementary feeding } & From variety of food & 197 (87.6\%) & $101(58.0 \%)$ \\
\hline & Not from variety of food & $28(12.4 \%)$ & $73(42.0 \%)$ \\
\hline \multirow[t]{2}{*}{ Safety of child feeding method } & With spoon/cup & 199 (88.4\%) & $116(66.3 \%)$ \\
\hline & With hand & $26(11.6 \%)$ & $59(33.7 \%)$ \\
\hline \multirow[t]{2}{*}{ Rotavirus vaccination status } & Vaccinated & $250(98.0 \%)$ & $212(85.1 \%)$ \\
\hline & Not vaccinated & $5(2.0 \%)$ & 37 (14.9\%) \\
\hline \multirow[t]{2}{*}{ Measles vaccination } & Vaccinated & $210(98.1 \%)$ & $|7|(81.8 \%)$ \\
\hline & Not vaccinated & $4(1.9 \%)$ & $38(18.2 \%)$ \\
\hline \multirow[t]{2}{*}{ Vitamin A supp. in last six months } & Received & 179 (77.5\%) & 137 (60.4\%) \\
\hline & Not received & $52(22.5 \%)$ & $90(39.6 \%)$ \\
\hline \multirow[t]{2}{*}{ Deworming status in the last six months } & Received & $88(80.0 \%)$ & $75(54.3 \%)$ \\
\hline & Not received & $22(20.0 \%)$ & $63(45.7 \%)$ \\
\hline \multirow[t]{2}{*}{ Diarrhea in under-five children } & Yes & $20(7.8 \%)$ & $71(27.8 \%)$ \\
\hline & No & $237(92.2 \%)$ & $184(72.2 \%)$ \\
\hline \multirow[t]{2}{*}{ Measles infection in the last 4 weeks } & Experienced & $0(0.0 \%)$ & $0(0.0 \%)$ \\
\hline & Not experienced & $257(100 \%)$ & $255(100 \%)$ \\
\hline
\end{tabular}

under-five children was $91(17.8 \% ;[95 \% \mathrm{CI}]=[14.5 \%$, $21.1 \%$ ], $p$-value < 0.001). It was $20(7.8 \%$; [95\% CI] $=$ $[4.5 \%, 11.1 \%], p$-value $<0.001)$ in model families, and 71 $(27.8 \% ;[95 \% \mathrm{CI}]=[22.3,33.3], p$-value $<0.001)$ in nonmodel families.

\section{Determinants of Childhood Diarrhea Among Participants in Wama Hagelo District, 2019}

Bivariate analysis showed that respondents' residence $(\mathrm{COR}[95 \% \mathrm{CI}]=0.7[0.2-12.7])$; family size $(\mathrm{COR}$ 


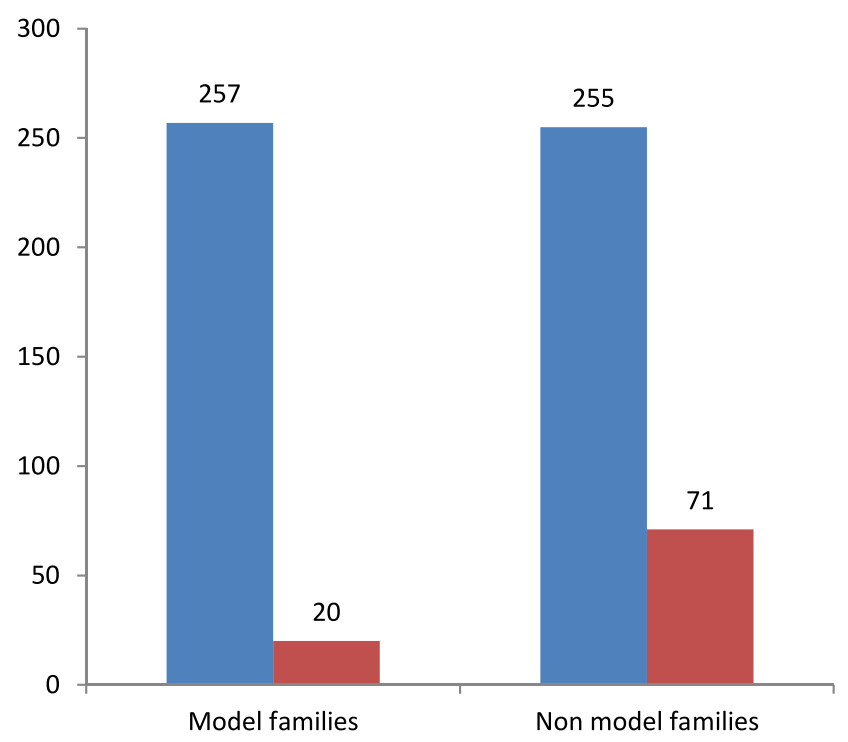

Figure I Prevalence of diarrhea among under-five-year-old children in health extension model and non-model families in Wama Hagelo woreda 2019. Notes: All surveyed households. __ Families with diarrhea among U5C.

$[95 \% \mathrm{CI}]=1.5[1.1-3.8])$; source of drinking water (COR $[95 \% \mathrm{CI}]=11.6[2.71-77.70])$; time to reach a water source $(\mathrm{COR}[95 \% \mathrm{CI}]=2[0.7-5.0])$; water treatment at the household level $(\mathrm{COR}[95 \% \mathrm{CI}]=1.2[0.5-3.2])$; number of under-five children in family, vaccination against Rotavirus, and vitamin A supplementation were variables for multivariable logistic regression among health extension model households (Table 4). Residence, family size, source of drinking water, storage of drinking water, and time taken to reach the water source, number of under-five children in the family, Rotavirus vaccination status of the index child, and vitamin A supplementation status were variables selected for the multivariable logistic regression model. Household health extension implementation status (being model or non-model) was also considered in multivariable logistic regression (Table 4).

The multivariable logistic regression showed that the occurrence of diarrhea among under-five children was about 2 times more likely among non-model families than model families (AOR $[95 \% \mathrm{CI}]=2.4[1.2-5.0]$ ). The odds of diarrhea among under-five children was 5.2 times higher among families who had $>5$ family members compared to those who had $\leq 5$ family members (AOR $[95 \% \mathrm{CI}]=3.4[1.7-17.6])$ in non-model families. But family size did not have an association with diarrhea in under-five children among model families. Diarrhea among under-five children was 5.5 times more likely among model families getting water from unimproved sources compared to model families getting water from improved sources (AOR [95\% CI] $=5.5$ [2.2-97.7]), while non-model families getting water from unimproved source had 7 times higher odds of under-five diarrhea (AOR [95\% $\mathrm{CI}]=7.2[1.6-13.2])$ than non-model families getting water from unimproved sources.

Presence of diarrhea in under-five children was 6 times more likely among non-model families who were not using latrines $(\mathrm{AOR}[95 \% \mathrm{CI}]=6.0[1.7-20.6])$ compared to non-model families who used latrines. But latrine utilization had no association with the occurrence of diarrhea among under-five children in model families. Children born at a health facility had $79 \%$ less likelihood of having childhood diarrhea (AOR $[95 \% \mathrm{CI}]=0.21[0.1-0.87]$ ) compared to the children born at home in model families (Table 4).

\section{Discussion}

The overall prevalence of diarrhea among under-five children in the study area was $17.8 \%$. This result was lower than other studies done in Harena Buluk woreda, Oromia Region, South East Ethiopia (with a prevalence of $28.4 \%),{ }^{15}$ in Jigjiga District, Somali Region, Eastern Ethiopia (27.3\%), ${ }^{16}$ and in Rural Areas of North Gondar Zone, Northwest Ethiopia (22.1\%). ${ }^{17}$ It might be due to variations in time. This means currently the Government is incapacitating the community to actively participate in communicable diseases prevention and control activities through implementing HEP, resulting in this lowering of diarrhea prevalence. ${ }^{10,11}$ In contrast, this result was higher than $12 \%$, the result of EDHS (Ethiopian Demographic Health Survey) 2016. ${ }^{18}$ This difference could be due to differences in sample size and study area.

The two-week childhood diarrhea prevalence in underfive children was $7.8 \%$ in model and $27.8 \%$ in non-model families. Childhood diarrhea in under-five children was 2.4 times more likely among health extension non-model families than model families. This was consistent with findings of studies done at Sheko District of a rural community, Southwest Ethiopia among health extension model and non-model households, $6.4 \%$ and $25.5 \%$, respectively, and in northern Ethiopia among model $(8.1 \%)$ and nonmodel (20.2\%) families. ${ }^{12,19}$ These consistent findings showed that as the government is focusing on the issues of community health care improvement through health extension workers delivering different services like training, support, and close follow-up of families on a package of basic and essential preventive and curative health 
Table 4 Predictors of Childhood Diarrhea Among Under-Five Children in Model and Non-Model Families in Wama Hagelo Woreda, East Wollega, Oromia, Ethiopia, 2019

\begin{tabular}{|c|c|c|c|c|c|}
\hline \multicolumn{6}{|l|}{ Model Families } \\
\hline \multirow[t]{2}{*}{ Variables } & \multirow[t]{2}{*}{ Categories } & \multicolumn{2}{|c|}{ Diarrhea Status } & \multirow[t]{2}{*}{ COR $(95 \% \mathrm{Cl})$} & \multirow[t]{2}{*}{ AOR $(95 \% \mathrm{Cl})$} \\
\hline & & Yes, $n$ (\%) & No, $n(\%)$ & & \\
\hline \multirow[t]{2}{*}{ Household health extension program implementation } & Non-model HH & 7I (27.8\%) & $184(72.2 \%)$ & 1 & I \\
\hline & Model HH & $20(7.8 \%)$ & $237(92.2 \%)$ & $4.6(2.7-7.8)$ & $2.4(1.15,5.00)^{*}$ \\
\hline \multirow[t]{2}{*}{ Residence of respondents } & Urban & I (0.4\%) & $8(3.1 \%)$ & 1 & 1 \\
\hline & Rural & $19(7.4 \%)$ & $229(89.1 \%)$ & $0.7(0.2,12.7)$ & $1.5(0.9,7.9)$ \\
\hline \multirow[t]{2}{*}{ Family size } & $\leq 5$ & II (4.\%) & $154(60 \%)$ & 1 & I \\
\hline & $>5$ & $9(3.5 \%)$ & $83(32.3 \%)$ & $1.5(1.1,3.8)$ & $1.04(0.3,3.4)$ \\
\hline \multirow[t]{2}{*}{ Types of source of water for drinking } & Improved & $16(6.2 \%)$ & $232(90 \%)$ & 1 & I \\
\hline & Unimproved & $4(1.6 \%)$ & $5(2.0 \%)$ & II.6 (2.71, 77.70) & $5.5(2.15,97.7)^{*}$ \\
\hline \multirow[t]{2}{*}{ Storage of water for drink in house } & Stored in jerry can & $16(6.2 \%)$ & $236(91.8 \%)$ & 1 & । \\
\hline & Stored in pot & $4(1.6 \%)$ & $\mathrm{I}(0.4 \%)$ & $59(6.23,59.24)$ & $1.5(0.12,8.6)$ \\
\hline \multirow[t]{2}{*}{ Time taken to reach water source } & $<15 \mathrm{~min}$ & $12(4.7 \%)$ & 177 (69\%) & 1 & I \\
\hline & $\geq 15 \mathrm{~min}$ & $8(3.1 \%)$ & $60(23.3 \%)$ & $2(0.7,5.0)$ & $3.1(0.71,13.7)$ \\
\hline \multirow[t]{2}{*}{ Household water treatment method } & Do not treat & $7(2.7 \%)$ & $95(37 \%)$ & 1 & I \\
\hline & Treat at home & $13(5.1 \%)$ & $142(55.3 \%)$ & $1.2(0.5,3.2)$ & $4.2(0.6,16.44)$ \\
\hline \multirow[t]{2}{*}{ No. of U5C in household } & 1 & $10(3.9 \%)$ & 138 (53.7\%) & 1 & I \\
\hline & $\geq 2$ & $10(3.9 \%)$ & 99 (38.5\%) & $1.4(0.6,3.5)$ & $2.2(0.5,8.2)$ \\
\hline \multirow[t]{2}{*}{ Place of childbirth } & Health facility & $19(7.4 \%)$ & $231(90.0 \%)$ & 1 & I \\
\hline & Home & I (0.4\%) & $6(0.8 \%)$ & $2(1.5,13.2)$ & $0.21(0.1,0.87)$ \\
\hline \multirow[t]{2}{*}{ Rotavirus vaccination status } & Vaccinated & $16(6.3 \%)$ & $228(91.8 \%)$ & 1 & । \\
\hline & Not vaccinated & $4(1.6 \%)$ & $6(0.4 \%)$ & $8.5(6.2,554.5)$ & $49.8(4.18,94.8)^{*}$ \\
\hline \multirow[t]{2}{*}{ Vitamin A supp. in last six months } & Received & II (4.8\%) & $168(72.7 \%)$ & 1 & । \\
\hline & Not received & $6(2.6 \%)$ & $46(20.0 \%)$ & $2(0.7,5.7)$ & $2.6(0.9 .5)$ \\
\hline \multicolumn{6}{|l|}{ Non-model families } \\
\hline \multirow[t]{2}{*}{ Residence of respondents } & Urban & $4(1.6 \%)$ & $5(2 \%)$ & 1 & I \\
\hline & Rural & $67(26.3 \%)$ & 179 (70.2\%) & $2.1(1.7,7.2)$ & $2.2(0.0,3.1 .0)$ \\
\hline \multirow[t]{2}{*}{ Family size } & $\leq 5$ & $25(9.8 \%)$ & $72(28.2 \%)$ & 1 & I \\
\hline & $>5$ & $46(18 \%)$ & $112(44 \%)$ & $1.2(0.7,2.1)$ & $5.2(1.7,17.6)^{*}$ \\
\hline \multirow[t]{2}{*}{ Types of source of water for drinking } & Improved sources & $36(14.1 \%)$ & $165(64.7 \%)$ & 1 & I \\
\hline & Unimproved & $35(13.6 \%)$ & $19(7.5 \%)$ & $18(3.7,90)$ & $7.2(1.6,13.2)^{*}$ \\
\hline \multirow[t]{2}{*}{ Storage of water for drink in house } & Stored in jerry can & $28(11 \%)$ & $183(71.8 \%)$ & 1 & 1 \\
\hline & Stored in pot & $43(17 \%)$ & I $(0.4 \%)$ & $28(7.2,112)$ & $2(0.95,8.76)$ \\
\hline \multirow[t]{2}{*}{ Time taken to reach water source in minutes } & $<15 \mathrm{~min}$ & $43(17 \%)$ & $127(49.8 \%)$ & 1 & I \\
\hline & $\geq 15 \min$ & $28(11 \%)$ & 37 (22.4\%) & $1.5(0.82,2.6)$ & $1.6(0.5,4.9)$ \\
\hline \multirow[t]{3}{*}{ Household water treatment method } & Do not treat & $65(25.5 \%)$ & $|4|(55.3 \%)$ & 1 & I \\
\hline & Treat at home & $6(2.4 \%)$ & $43(17 \%)$ & $0.3(0.1,0.7)$ & $0.6(0.1,2.8)$ \\
\hline & Use partially & $44(17.3 \%)$ & 47 (18.4\%) & $4.8(2.6,8.5)$ & $0.8(0.2,3.6)$ \\
\hline \multirow[t]{2}{*}{ Family using latrine } & Yes & $39(15.3 \%)$ & $176(69 \%)$ & 1 & 1 \\
\hline & No & $32(12.5 \%)$ & $8(3.1 \%)$ & $18(7.7,42.2)$ & $6.0(1.8,20.6)^{*}$ \\
\hline No. of U5C in household & 1 & $20(7.8 \%)$ & $114(44.7 \%)$ & 1 & I \\
\hline & $\geq \underline{2}$ & $51(20 \%)$ & $70(27.5 \%)$ & $4.2(2.3,7.6)$ & $2.3(0.8,7.1)$ \\
\hline
\end{tabular}

(Continued) 
Table 4 (Continued).

\begin{tabular}{|c|c|c|c|c|c|}
\hline \multicolumn{6}{|l|}{ Model Families } \\
\hline \multirow[t]{2}{*}{ Variables } & \multirow[t]{2}{*}{ Categories } & \multicolumn{2}{|c|}{ Diarrhea Status } & \multirow[t]{2}{*}{$\operatorname{COR}(95 \% \mathrm{Cl})$} & \multirow[t]{2}{*}{ AOR $(95 \% \mathrm{Cl})$} \\
\hline & & Yes, $n$ (\%) & No, $n(\%)$ & & \\
\hline \multirow[t]{2}{*}{ Rotavirus vaccination status } & Vaccinated & $37(15 \%)$ & 175 (70.3\%) & 1 & \\
\hline & Not vaccinated & 33 (13.3\%) & $4(1.6 \%)$ & $39(13.3,116.9)$ & $10.9(2.87,41.05)^{*}$ \\
\hline \multirow[t]{2}{*}{ Vitamin A supp. in last six months } & Received & $26(11.5 \%)$ & $111(49 \%)$ & 1 & \\
\hline & Not received & $38(16.7 \%)$ & $52(23 \%)$ & $3.2(1.7,5.7)$ & $3.2(1.4,7.2)^{*}$ \\
\hline
\end{tabular}

Note: *Statistically significant variables in multivariable logistic regression.

services targeting to the reduction of communicable diseases especially diarrhea in under-five. It was during this time that a significant reduction of diarrhea prevalence is revealed in such families of HEP best implementers than other non-model families. ${ }^{10,20}$

A household with many family members might have poor personal and environmental hygiene and poor food handling practices. In this study, under-five children living with more than five family members were more vulnerable to diarrhea than those living with a household with a small family size among non-model families. This finding was in line with studies conducted in Rural Areas of North Gondar Zone, Northwest Ethiopia, and Serbo Town, Jimma Zone South West Ethiopia. ${ }^{17,21}$ This means when there is overcrowding in the household, the chances of disease transmission through contamination of water and food as well as poor personal hygiene and environmental sanitation would be high, leading to the occurrence of childhood diarrhea. ${ }^{3,23}$ Family size did not have an association with diarrhea among under-five children in health extension package model families. It might be that, if all other risk factors of diarrhea are kept constant, the number of family members alone cannot lead to the occurrence of diarrhea provided that the family life is healthy.

The type of sources of water for drinking had an association with diarrhea among under-five children in both model and non-model families. Hence the occurrence of diarrhea among under-five children was more common among both model and non-model health extension families using water from an unimproved source than among model and non-model families using water from an improved source. This was similar to the findings of other studies conducted in Northern Nigeria where childhood diarrhea was 1.2 times more likely to occur in families getting water from an unimproved source than in families getting from improved sources, ${ }^{24}$ and in
Medebay Zana District of Northwest Tigray, where it was 1.8 times more likely in families using unimproved water sources than in families using improved sources. ${ }^{25}$ Water from an improved water source tends to be less contaminated by pathogenic microorganisms than water from an unimproved water source, and contaminated water may contain microorganisms from human and animal feces, leading to the occurrence of communicable diseases especially diarrhea in children; hence access to pure water alone significantly reduces childhood diarrhea in children by $28 \%-48 \%{ }^{26}$

Using latrines was an independent predictor of diarrheal diseases in this study. This study revealed that the likelihood of diarrhea among non-model families not using latrines was 6 times that of non-model families using latrines, irrespective of latrine type. This is in line with previous similar studies in Rural Settings of Dangla District, Northwest Ethiopia, and Jigjiga District, Somali Region, Eastern Ethiopia. ${ }^{16,27}$ Using a latrine is a sign of sanitary conditions. It is also the indication of low transmission of disease pathogens through fecal contamination, and hence the prevalence of childhood diarrhea in families having a latrine was found to be lower than in those families not using a latrine. Since all model families were using a latrine, an association between using a latrine and diarrhea among under-five children was not revealed.

This study indicated that the birthplace of the index child was an independent predictor of diarrhea among under-five children. In this study, under-five children born at health facilities had $79 \%$ less risk of having diarrhea among model families compared to those born at home. The finding was consistent with the study done in Shake Zone, Southwest Ethiopia. ${ }^{28}$ This means most mothers delivering at health facilities are regularly trained in the form of pregnant women conferences on how to take care of their pregnancy, risks, place of delivery, sanitation, 
and hygiene, on how to feed, care, and keep their child before, during delivery, and postnatally, and as a result there would be the chance of decreasing the occurrence of communicable diseases particularly diarrhea in their family and children, leading to lowering of childhood diarrhea in children of such families.

Rotavirus is one of the causes of diarrhea among under-five children which can be prevented by Rotavirus vaccination. In this study, being vaccinated against Rotavirus was an important protector of childhood diarrhea. Children vaccinated against Rotavirus were less likely to have diarrhea among model and non-model families than their unvaccinated counterparts. This finding was consistent with other findings regarding the association of diarrhea in under-five children and the Rotavirus vaccination status of the children. ${ }^{24,29}$ The justification for this consistent finding is that among microorganism-specific causes of diarrhea Rotavirus and Escherichia coli are among the leading ones, especially in under-five children, and if children are vaccinated against this virus at the appropriate age they will be likely to experience less diarrheal illness than children not vaccinated. ${ }^{3,30}$

The study also showed that vitamin A supplementation for under-five children was an independent predictor of childhood diarrhea. In this study, the odds of diarrhea among under-five children of non-model families who have not supplemented vitamin A within six months before the survey were about 3 times greater than the odds of childhood diarrhea in under-five children of non-model families who were supplemented with vitamin A during the same time. The finding was in line with other similar studies in Global Burden of Disease Study 2016 and Hawassa, South Ethiopia. ${ }^{3,24}$ Vitamin A supplementation for under-five children is believed to decrease child morbidity and mortality, including from diarrhea, by enhancing the immune system if it is given to children at an appropriate age and interval. In addition to this fact, for several years, six-monthly routine vitamin A supplementation programs of under-five children in Ethiopia had been integrated with other under-five services like deworming, screening for malnutrition, and health education on child health care, and therefore these integrated services might have contributed to decreasing childhood diarrhea in children who got the supplementation. ${ }^{31}$

According to this study, socioeconomic factors like residence, age, sex, religion, ethnicity, occupation, and educational level of the respondents and the child's father, monthly family income, $\mathrm{HH}$ water storage status, $\mathrm{HH}$ water treatment, handwashing with soap at critical times, type of latrine, latrine hand washing facility, commonly using a latrine, solid and liquid waste disposing status, index child sex, age, breastfeeding status, age at starting complementary feeding, how to feed a child in the household, child deworming, and measles vaccination status were not found to be the predictors of childhood diarrhea. This finding was in contrast to other similar studies. ${ }^{15,27,28}$ This was because currently many socioeconomic factors like sex, religion, ethnicity, income, occupation, and others could not negatively influence families provided that they have knowledge and skills on prevention of communicable diseases, especially those related to poor hygiene and sanitation. The reason for other variables not having an association with childhood diarrhea was due to the homogeneous effect of factors with other significant predictors, because when one program has been implemented the others are usually implemented in integration simultaneously and separately.

Despite this interesting finding, the study had limitations. First, there might be social desirability bias related to some health extension packages which might have an impact on reporting appropriate health extension packages implementation by households. Second, the study was a cross-sectional comparative study, which may not set a temporal relationship between cause and effect.

\section{Conclusion}

Diarrhea was more frequent among non-model than model families. Being a non-model family of health extension programs, large family size of greater than five members, using water from unimproved sources, not using a latrine, a child not born at the health facility, absence of childhood vaccination for Rotavirus, and no vitamin A supplementation for children were negatively associated with the occurrence of childhood diarrhea in under-five children. Therefore, the woreda health office and the health extension workers should intensify the implementation of health extension packages among health extension model households. The health extension non-model households should be encouraged by the woreda health office and health extension workers to become model households through intensive information education and communication on implementation and advantages of implementing all health extension packages. 


\section{Abbreviations}

CHIS, Community Health Information System; CI, confidence interval; CSA, Central Statistical Agency; EBF, exclusive breastfeeding; EDHS, Ethiopian Demographic Health Survey; HEP, Health Extension Programs; HEW, health extension worker; HH, household; NGO, non-governmental organization; ODF, open-defecation-free; SPSS, Statistical Packages for Social Science; SRS, simple random sampling; VIF, variance inflation factors; U5C, under-five children; UNICEF, United Nations International Children's Emergency Fund.

\section{Data Sharing Statement}

The data used to support the findings of this study are available from the corresponding author upon request.

\section{Ethical Consideration}

This study was conducted in line with the Helsinki Declaration of health research. ${ }^{32}$ Ethical clearance was obtained from Wollega University, School of Graduate Studies Ethical Review Committee. Permission for conducting the study was secured from the district health office. Written consent was obtained from all the study participants after they had been briefed about the objectives and the aim of the research.

\section{Acknowledgments}

First, we would like to thank Wollega University for providing ethical permission to undertake this study. We also acknowledge the administrators and staff of the Wama Hagelo Health Office, the respective health centers and health posts for their cooperation in providing the necessary baseline data of the study area and for their great support in the overall data collection process. Finally, our great full appreciation would be for all families and their child caregivers for the excellent and uninterrupted cooperation they made with data collectors during data collection.

\section{Author Contributions}

All authors made a significant contribution to the work reported, whether that is in the conception, study design, execution, acquisition of data, analysis and interpretation, or in all these areas; took part in drafting, revising or critically reviewing the article; gave final approval of the version to be published; have agreed on the journal to which the article has been submitted; and agree to be accountable for all aspects of the work.

\section{Funding}

There is no funding to report.

\section{Disclosure}

The authors report no conflicts of interest in this work.

\section{References}

1. World Health Organization. The treatment of diarrhea: a manual for physicians and other senior health workers, 4th rev. World Health Organization; 2005. Available from: https://apps.who.int/iris/handle/ 10665/43209. Accessed September 13, 2021.

2. Gill S, Cavill S, Hayes J. Diarrhoea dialogues: from policies to progress: a call for urgent action to prevent the biggest killer of children in sub-Saharan Africa; 2012.

3. Clifton EU, Douglas AL, Jorge RM. Diarrhea and dehydration, module 6; 2016. Available from: https://www.aap.org/enus/ Documents/Module_6_Eng_FINAL_10182016.pdf. Accessed September 13, 2021.

4. U.S. Department of Health and Human Services; Centers for Disease Control and Prevention. Diarrhea: common illness, global killer [fact sheet]; 2018. Available from: https://www.cdc.gov/healthywater/pdf/ global/programs/Globaldiarrhea508c.pdf. Accessed September 21, 2021.

5. Keusch GT, Fontaine O, Bhargava A, et al. Diarrheal Diseases. In: Jamison DT, Breman JG, Measham AR, et al, editors. Disease Control Priorities in Developing Countries. 2nd edition. Washington (DC): The International Bank for Reconstruction and Development/The World Bank; New York: Oxford University Press; 2006:Chapter 19. Available from: https://www.ncbi.nlm.nih. gov/books/NBK11764/..

6. USAID Global. Declaration on scaling up treatment of Diarrhea and Pneumonia; 2013. Available from: https://www.usaid.gov/sites/ default/files/documents/1864/PneumoniaDiarrheaDeclaration.pdf. Accessed September 13, 2021.

7. World Health Organization. Readings on Diarrhoea; Student Manual ;1992. Available from: http://apps.who.int/iris/bitstream/han dle/10665/40343/9241544449.pdf?sequence=1. Accessed September 21, 2021.

8. Woldu W, Bitew BD, Gizaw Z. Socioeconomic factors associated with diarrheal diseases among under-five children of the nomadic population in northeast Ethiopia. Trop Med Health. 2016;44(1):1-8. doi:10.1186/s41182-016-0040-7

9. Troeger C, Blacker BF, Khalil IA, et al. Estimates of the global, regional, and national morbidity, mortality, and aetiologies of diarrhea in 195 countries: a systematic analysis for the global burden of disease study 2016. Lancet Infect Dis. 2018;18:12111228

10. Federal Democratic Republic of Ethiopia, Ministry of Health. The health sector transformation plan (HSTP); 2015. Available from: http://indepth-network.org/iscs/isc2015presentations/Ethiopia\% 20Health\%20Sector\%20Transformation\%20Plan.pdf. Accessed September 21, 2021

11. Wang H, Tesfaye R, Ramana NV, Chekagn CT. Ethiopia Health Extension Program: An Institutionalized Community Approach for Universal Health Coverage. World Bank Publications; 2016.

12. Gebrezgiabher BB, Abraha TH, Tetemke D, et al. Diarrheal disease in under-five children among model and non-model families in northern Ethiopia, 2017: a comparative cross-sectional study. BMC Res Notes. 2019;12:1-7. doi:10.1186/s13104-0194322-0

13. Sharma SK, Mudgal SK, Thakur K, Gaur R. How to calculate sample size for observational and experimental nursing research studies? Natl J Physiol Pharm Pharmacol. 2020;10(01):1-8. 
14. Kimani HM. Assessment of diarrhoeal disease attributable to water, sanitation and hygiene among under five in Kasarani, Nairobi County[master's thesis]. Nairobi: Kenyatta University; 2013. Available from: https://ir-library.ku.ac.ke/bitstream/handle/ 123456789/9200/Humphrey\%20Mbuti\%20Kimani.pdf? sequence= 3\&isAllowed=y. Accessed September 21, 2021.

15. Alonso-Navarro H. Prevalence of diarrhea and associated factors among under five years children in HarenaBuluk Woreda Oromia Region, South East Ethiopia, 2018. Journal of Public Health International. 2018;1(2):9-26. doi:10.14302/issn.2641-4538.jphi-182470

16. Jonathan B. Hosmer-Lemeshow goodness of fit test for logistic regression. Available from: https://thestatsgeek.com/2014/02/16/thehosmer-lemeshow-goodness-of-fit-test-for-logistic-regression/. Accessed September 13, 2021.

17. Hashi A, Kumie A, Gasana J. Prevalence of diarrhoea and associated factors among under-five children in Jigjiga District, Somali Region, Eastern Ethiopia. Open J Prev Med. 2016;06(10):233-246. doi:10.4236/ojpm.2016.610022

18. Menberu MA, Guadu T, Cherkos DH, et al. Diarrhea prevalence and sociodemographic factors among under-five children in rural areas of North Gondar Zone, Northwest Ethiopia. Int J Pediatr. 2018;2018:1-8.

19. Central Statistical Agency (CSA) [Ethiopia] and ICF. Ethiopia Demographic and Health Survey 2016. Addis Ababa, Ethiopia; Rockville, ML, USA: CSA and ICF; 2016.

20. Gebru T, Taha M, Kassahun W. Risk factors of diarrhoeal disease in under-five children among health extension model and non-model families in Sheko district rural community, Southwest Ethiopia: a comparative cross-sectional study. BMC Public Health. 2013;14:1-6.

21. Ayalew AM, Mekonnen WT, Abaya SW, Mekonnen ZA. Assessment of diarrhea and its associated factors in under-five children among open defecation and open defecation-free rural settings of Dangla District, Northwest Ethiopia. J Environ Public Health. 2018;2018. doi:10.1155/2018/4271915

22. Kasye DG, Garoma NH, Kassa MA. Assessment of the prevalence of diarrheal disease under-five children Serbo Town, Jimma Zone South West Ethiopia. Clin Mother Child Health. 2018;15(1). doi:10.4172/ 2090-7214.1000281

23. UNICEF/World Health Organization. Diarrhoea - why children are still dying and what can be done, UNICEF/WHO 2009; 2009. Available from: https://www.who.int/publications/i/item/ 9789241598415. Accessed September 27, 2021.
24. Berhe F, Berhane Y. Under-five diarrhea among model household and non-model households in Hawassa, South Ethiopia: a comparative cross-sectional community-based survey. BMC Public Health. 2014;14(187). doi:10.1186/1471-2458-14-187

25. Hussein H. Prevalence of diarrhea and associated risk factors in children under five years of age in Northern Nigeria: a secondary data. Anal Niger Demogr Heal Surv. 2017;10:1-10.

26. Asfaha KF, Tesfamichael FA, Fisseha GK, et al. Determinants of childhood diarrhea in Medebay Zana District, Northwest Tigray, Ethiopia: a community based unmatched case-control study. $B M C$ Pediatr. 2018;18(1):1-9. doi:10.1186/s12887-018-1098-7

27. World Health Organization. Preventing diarrhea through better water, sanitation, and hygiene; 2014:1-48. Available from: http://apps.who. int/iris/bitstream/handle/10665/150112/9789241564823_eng.pdf? sequence=1. Accessed September 21, 2021.

28. Ayalew AM, Mekonnen WT, Abaya SW, Mekonnen ZA. Assessment of diarrhea and its associated factors in under-five children among open defecation and open defecation-free rural settings of Dangla District, Northwest Ethiopia. J Environ Public Health. 2018;2018:18. doi:10.1155/2018/4271915

29. Gashaw TA, Walie YM. Prevalence and determinate factors of diarrhea morbidity among under-five children in Shake Zone, Southwest Ethiopia, a community based cross-sectional study. Arch Commun Med Public Heal. 2019;1:008-014. doi:10.17352/2455-5479.000046

30. Gedamu G. Magnitude and associated factors of diarrhea among under five children in FartaWereda. Qual Prim Care. 2017;25:199-207.

31. Alexander L. Addressing diarrhea through public health action: the case of an informal settlement in Sub-Saharan Africa; 2012. Available from: https:/www.oerafrica.org/resource/addressing-diar rhea-through-public-health-action-case-informal-settlement-subsaharan. Accessed September 21, 2021.

32. World Medical Association. World Medical Association Declaration of Helsinki: ethical principles for medical research involving human subjects. JAMA. 2013;310(20):2191-2194. doi:10.1001/jama.2013.281053
Journal of Multidisciplinary Healthcare

\section{Publish your work in this journal}

The Journal of Multidisciplinary Healthcare is an international, peerreviewed open-access journal that aims to represent and publish research in healthcare areas delivered by practitioners of different disciplines. This includes studies and reviews conducted by multidisciplinary teams as well as research which evaluates the results or conduct of such teams or healthcare processes in general. The journal covers a very wide range of areas and welcomes submissions from practitioners at all levels, from all over the world. The manuscript management system is completely online and includes a very quick and fair peer-review system. Visit http://www.dovepress.com/testimonials. php to read real quotes from published authors. 